\title{
CULTURAL VALUES IN ORAL LITERATURE OF KRINOK: ANTROPOLINGUISTIC STUDY
}

\author{
Arie Sugiyartati, Burhanuddin Arafah, Fathu Rahman, Mustafa Makka \\ Faculty of Cultural Sciences, Hasanuddin University, Makassar, Indonesia \\ E-mail: ariesugiyartati@staff.gunadarma.ac.id
}

Received: 21 October 2020

Accepted: 11 December 2020

\begin{abstract}
This study aimed to examine the uniqueness of the Krinok oral literary structure, the meaning of traditional and cultural values, and the variety of cultural values possessed by the Batin people in Bungo Regency, Jambi, which focused on the Krinok speakers in the area. This research applied qualitative approach using anthropolinguistic studies following Alessando Duranti (2001) and William A. Foley (1997). Data collection was carried out by means of interviews and literature study. Interviews were carried out when meeting with informants of Krinok and the interviews were recorded. The results showed that the uniqueness of Krinok oral literature lies in the structure of the pantun 'a typical Indonesian four-line verse' which has a high pitch at the beginning of the speech, the repetition of the first and second verse and all of which show all the competencies, indexicality, performance that exist in Duranti's anthropolinguistic theory. There are also cultural values, as stated by Djamaris in his theory (1993: 2-3), the concept of cultural values in human relations with God, cultural values of human relations with nature, cultural values of human relations with society, cultural values of human relations with other humans, and cultural values of human relations with themselves.
\end{abstract}

Keywords: anthropolinguistics, cultural values, oral literature.

\section{Introduction}

Jambi Province as part of the archipelago has diversity of cultures and traditions. Diversity of the ethnic communities also shows diversity of cultures and traditions in this region. One of the ethnic communities is the Batin Tribe. This ethnic group inhabits most areas in Jambi and inherits an oral literature called Krinok.

Oral literature is also a particular type of spoken literary work spreading orally, anonymously and depicting the life of past community as said by Shipley (1962). Oral literature is a social creation and institution using language as medium (Arafah, Jamulia\& Kaharuddin. 2020). Hence, oral literature is a part of disclosing the literary world unseparated from the influence of new values living and developing in society. Many cases of oral traditional literature are no longer known to the public, even though this tradition, seen anthropologically, is shaped by the community's traditions (Arafah \& Kaharuddin, 2019). This also means that there are values ever embraced by the community as the creators.

The oral literature of Batin Jambi called Krinok is interesting to study. As a cultural product, Krinok oral literature developed in Batin tribe community as crystallization of the community's culture with natural process. And that society is formed through a long winding 
Cultural Values in Oral Literature of Krinok: Antropolinguistics Study, Arie Sugiyartati, Burhanuddin Arafah, Fathu Rahman, Mustafa Makka

history leaving a legacy eventually becomes a cultural heritage (Andi \& Arafah, 2017, Arafah\& Kaharuddin 2019)

Krinok is supported by a regional language, namelyBatin Malayspoken in Bungo Regency, Jambi Province. Batin Malay is one of the Austronesian language families, which belongs to the Sumatran language group.

"People Perception toward the Krinok Performance in Marriage ceremony in Bungo Regency" by Rahayu (2012) states that Krinok is an art uniting people in intimacy, reflecting the social values of society, and educating the local community. The people feel that Krinok is their identity and as an entertaining traditional music and making people to communicate one another.

\section{Literature Review}

"Public Perception of Krinok Performance at a Wedding in Bungo Regency "by Rahayu (2012) that krinok is an art that unites the community in intimacy, reflects the social values of the community, and educates the local community. "Cultural Values in Oral Literature of Tale Kerinci: Structural and Semiotic Studies", by Nazurty (2013). In this study, the researcher found that Tale is a literary work that is included in the type of poetry. Tale is a folk song that belongs to the old poetry work or conventional poetry. The cultural values depicted in the Tale relating to human relations with God. Another is conducted by (Arafah et al., 2020)"An Anthropological Linguistic Study on Maccera Bulung Ritual, in searching all possible meanings of maccera' bulung ritual also in Luwu community resulting ecological and cultural meaning.

In anthropolinguistic term, there are at least three important relationships that need attention. First, the relationship between one language and the culture concerned, means that when studying a culture, we also have to learn the language, and when we learn the language we also have to study the culture (Arafah, 2003). Second, the relationship between language and culture in general means that when there is one language in a society, there is also one culture in that society. Language indicates culture, language difference means cultural difference or vice versa. Third, the relationship between linguistics as a science of language and anthropology as a cultural science. (Sibarani 2013, Arafah, \& Bahar. 2015).

Foley (1997) defines anthropological linguistics as a sub-discipline of linguistics dealing with the place of language in cultural and social contexts that have a role to support and forge the social structures and cultural practices.Through the linguistic anthropology approach, we examine what people do with the language and the speech produced; silence and gesture are associated with the context in which it occurs (Duranti, 2001, Kaharuddin, 2018).

There are several analytical ideas that underlie the anthropological linguistics, namely: 1) competence and performance, 2) indexicality, and 3) participation (Duranti, 1997: 14-21). The concept of competence and performance is a two-key terms in generative grammar developed by Chomsky (1965). Competence is a system of knowledge of a language (a system of culture) which is controlled by the speakers of the language. On the other hand, performance is the real use of language in actual communication situation which is a reflection of the language system in the mind of the speaker. The concept of indexicality concerns with the sign having an existential relationship with the one referred to. The concept of participation is intended as a speaker's involvement in producing acceptable forms of speech (Duranti, 1997), Kaharuddin, Hikmawati, Arafah, 2019). 


\section{Research Method}

This research uses qualitative approach. Since this research is a type of cultural literature research in the realm of linguistic studies, namely the disclosure of cultural values of Krinok oral literature, it made use of content analysis method with an anthropoliguistic approach. The method was used to reveal cultural values in Krinok oral literature in relation to competence and performance, indexability, participation contained therein as well as the functions and influences on where the language is spoken, cultural/social context and cultural/social structures in the bolstering community (Kaharuddin, 2019).

\section{Discussion}

The discussion and the analysis of this study are conducted by using anthropolinguistic approach as they are presented as follows:

Sepucuk Jambi sembilan lurah

(One Jambi nine village heads)

batangnyo alam brajo titin treh betanggo batu

(The trunk natural with stone bridge terrace)

adat bersendi sarak, sarak bersendi kitabullah

(custom is based on Islamic law, Islamic law is based on Kitabullah 'The Holy Qur'an)

dari dulu sampainyo kini

(from long ago to the present)

dari kecik sampainyo gedang

(from small to large)

itunyo adat nan kito pakai

(that's the custom we use)

jangan diasak jangan dipisah adat dipakai dari dulunyo

(do not move, do not separate, custom was used from the past)

One of the Krinoks having philosophical meaning of Jambi community, Jambi, sepucuk Jambi sembilan lurah is the slogan of Jambi community, which is based on customs and the holy Al-Qur'an from ancient times to the present that could not be separated and moved.

Competence: Sepucuk Jambi sembilan lurah is the life slogan of Jambi people, which has existed from ancient times to the present. Performance: Jangan diasak jangan dipisah adat dipakai dari dulunyo 'Don't move it, don't separate it from the past'. This custom cannot be separated from everyday life. Indexicality: Batangnyo alam brajo titin treh betanggo batu, Berasal dari raja dengan jembatan bertangga batu, 'Originating from a king with a stone stepped bridge'. The trunk here is likened to the customs originated from the king /God, the stone-stepped bridge is likened to a multilevel journey of life. Participation: the speaker's involvement in producing an acceptable form of utterance as in the lines: Itunyo adat nan kito pakai, jangan diasak jangan dipisah adat dipakai dari dulunyo, which means that in everyday life, people still uphold the customs.

Cultural values in a literary work (Krinok oral literature) can be applied in social life, such as human relations with God, human relations with nature, human relations with society, human relations with other humans, and human relations with himself (Djamaris, 1993). This concept of cultural values becomes the theoretical base of this research because this concept of cultural values can be studied semiotically in Krinok oral literature. In addition to the concept of cultural values in human relations with God, cultural valueof human relations with nature, cultural valuesof human relations with society, cultural values of human relations 
with other humans, and cultural valuesof human relations with themselves, there are also concepts of cultural value be able to encourage development, such as cultural values that endure suffering in characteristic, obliged to strive and work together (Koentjaraningrat, 1984).

Values in literary works can absorbed by the literary lovers if he has gained experience in enjoying the literary work he is reading. In other words, only readers who have successfully acquired literary experience can gain values or benefits in literature. Krinok oral literature is a description of the ethical, moral, and religious teachings that are used in everyday life in Batin tribe community. This means that Krinok is a reflection of the cultural values of Batin Jambi society.

Furthermore, the concept of cultural values used in this study is the concept of cultural values proposed by Djamaris et al. (1993), namely: 1) The relationship between humans and God, Krinok that reflects the relationship between humans and God can be seen in the line: Adat bersendi pada sarak dan sarak bersendi pada kitabullah (The Holy Qur'an). In the expression, it is stated that adat 'custom' is based on syarak 'Islamic law' and syarak is connected to the Kitabullah (The Holy Qur'an). The life of the community must be in accordance with the law inforcement in the area, in this case the customary law which comes from religious law, in this context, Islam. Aro kain di tengah laman, Lambat laun minta ke Tuhan. This expression reveals that when there is an obstacle in the middle of the road, we will gradually beg God, too. In life, people will usually try an effort but they will then beg God. 2) The relationship between humans and nature, Krinok that reflects the relationship between humans and nature can be seen in the lines: Sungai tuak sungai merantih, sungai kasai padi mumbo. When planting rice, humans really expect the water in the river. Tino bawah titin, tino dari sungai samak, 'The girls under the bridge, the child from Samak River', These lines reflect the habit of girls washing clothes in the river so that they seem to gather under the bridge. 3) Human relations with society, reflected in Krinok: Mintak lahnyo maaf kepado tuolah dan mudo sebelum kito bapisah lahnyo kini. The lines mean that one should always ask for apology to the young or the old before separating or leaving (in this case wander about). 4) Human relations with other humans are reflected in the lines: Ngan disusun jari nan sepuluh, Minta tabik pado nan tuo, Nyanyi baik dak kan ado, Untuk pelebuh hati nan ibo. These lines tell people to ask for advice from the elderly. Parents should be respected by asking for opinions and suggestions by the younger people. 5) Human relations with themselves are reflected in the lines: Badanku nian nan salah sukat, Badanku nian yoo dek nan salah sukat. The lines tell that unhealthy body can do no work.

\section{Conclusion}

From the description above, it can be concluded that Krinok is unique; it is a poem spoken with themes of sadness, lamentation, feelings of compassion, as well as falling in love. Krinok at this time has three functions: as a self-entertainer, to drive away wild animals and to attract women to marry with. Because of its function as self-entertainer, there are no standard of Krinok lyrics. Each chanter is free to voice their hearts, whether happy or sad.

The language used in Krinok is Bungo language. In this case the diction in Krinok oral literature is different from everyday language because the language in Krinok is full of choices of beautiful words and phrases, full of philosophical meanings and rich in taste values. Rhythmic characteristics in Krinok are identified as: 1) High notes at the beginning of the verse; 2) short rhythm in each greeting word; 3 ) there is a repeat rhythm at the beginning of each verse. 
Function of Krinok is to convey (forward) messages, advice, and knowledge containing values and norms based on religion and customs believed by the local community. In addition to conveying messages and advice and knowledge, Krinok also has a reminder function (alarm) and an entertaining function and informs the oral traditions of the Batin society of Jambi Malay ethnic community. Cultural values contained in Krinok oral literature are cultural values between humans and God, cultural values between humans and nature, cultural values between humans and humans, and cultural values between humans and themselves.

\section{References}

Andi, K., \& Arafah, B. (2017). Using needs analysis to develop English teaching materials in initial speaking skills for Indonesian college students of English. The Turkish Online Journal of Design, Art and Communication (TOJDAC), Special Edition, 419-436. http://www.tojdac.org/tojdac/VOLUME7-APRLSPCL_files/tojdac_v070ASE145.pdf.

Arafah, B. (2003). Warisan budaya, pelestarian dan pemanfaatannya. Makassar: Fakultas Ilmu Budaya.

Arafah, H. B., \& Bahar, A. K. (2015). The Art of Developing Speaking As a Performance (Promoting Formal Uses of Public Speaking Skills in English for Making Speeches and Oral Presentation). https://scholar.google.co.id/citations?user=xqRE39AAAAAJ\&hl=en.

Arafah, B., \& Kaharuddin. (2019). The Representation of Complaints in English and Indonesian Discourses.Opción, 35, 501-517. https://www.researchgate.net/ publication/339160079_The_Representation_of_Complaints_in_English_and_Indone sian_Discourses.

Arafah, B. \& Kaharuddin. (2019). The Idol: A Model for Incorporating Literature in ELT. KnE Social Sciences, 43-59. https://knepublishing.com/index.php/Kne-Social/article/ view/4829.

Arafah, B., Thayyib, M., Kaharuddin, \& Sahib, H. (2020). An Anthropolongical Linguistic Study on Maccera' Bulung Ritual. Opcion, 36 (special Edition 27), 1592-1606. https://scholar.google.co.id/citations?user=xqRE39AAAAAJ\&hl=en.

Arafah, B., Jamulia. J., \& Kaharuddin. (2020). The Speaking People of South Halmahera Languages: A study on Cultural Relationship.Journal of Talent Development and Excellence, 12(3s), 1331-1340. https://scholar.google.co.id/citations? user $=x q R E 39 A A A A A J \& \mathrm{hl}=\mathrm{en}$.

Chomsky, Noah. (1965). Aspect of the Teory of Syntax. Cambrigde: MIT Press.

Djamaris. (1993). Nilai Budaya Dalam Beberapa Karya Nusantara: Sastra Daerah Sumatra. Jakarta: Depdikbud.

Duranti, Alessandro. (2001). A Companion to Linguistic Anthropology. Malden: Blackwell.

Foley, W. (1997). Anthropological Lingusitics: An Introduction. Malden: Blackwell

Kaharuddin, A. (2018). The communicative grammar translation method: a practical method to teach communication skills of English. ETERNAL (English, Teaching, Learning, and Research Journal), 4(2), 232-254. http://journal.uin-alauddin.ac.id/index.php/ Eternal/article/view/6292/0.

Kaharuddin, Hikmawati, Arafah, B. (2019). Needs Analysis on English for Vocational Purpose for Students of Hospitality Department.KnE Social Sciences, 344-387. https://knepublishing.com/index.php/KnE-Social/article/view/4869.

Kaharuddin, A. (2019). The Power of English: Recognizing and Utilizing the Tremendous Impact of the English Language on the Community. English Language Teaching for EFL Learners, 1(1), 39-48. http://journal.uin-alauddin.ac.id/index.php/elties/ article/view/7625. 
Cultural Values in Oral Literature of Krinok: Antropolinguistics Study, Arie Sugiyartati, Burhanuddin Arafah, Fathu Rahman, Mustafa Makka

Koentjaraningrat. (1994). Kebudayaan Jawa. Jakarta: Balai Pustaka.

Nazurty, Hajjah. (2013). Nilai-Nilai Budaya dalam Sastra Lisan Tale Kerinci: Kajian Struktural dan Semiotik. Disertasi. Jakarta: Program Pascasarjana FIB UNJ.

Rahayu, Gusti. (2012). persepsi Masyarakat Terhadap Pertunjukan Krinok pada Acara Pesta Perkawinan di Kabupaten Bungo. Thesis of Postgraduate Padang: Universitas Negeri Padang.

Shipley, Yosef T. et. al. (1962). Dictionary of World Literature. Caterson, New Jersey: Littefiel, Ada, \& Co.

Sibarani, Robert. (2013). Pendekatan Antrolinguistik dalam Menggali Kerifan Lokal sebagai Identitas Bangsa. Jurnal the 5th International Conference on Indonesian Studis: Ethnicity and Globalitation.https://icssis.files.wordpress.com/2013/09/2013-0223.pdf. 